\title{
Highlights, predictions, and changes
}

\author{
Kuan-Teh Jeang
}

\begin{abstract}
Recent literature highlights at Retrovirology are described. Predictions are made regarding "hot" retrovirology research trends for the coming year based on recent journal access statistics. Changes in Retrovirology editor and the frequency of the Retrovirology Prize are announced.
\end{abstract}

I recently wrote an editorial in Cell and Bioscience on the use of a novel algorithm to predict the future $\mathrm{H}$-index of a scientist and his/her likelihood of "success" [1]. In a similar vein, as we approach the end of a calendar year, I examined access statistics of recently published Retrovirology papers to predict areas of highlighted interest for the coming year.

In parsing access frequencies over the preceding 12 months to recent Retrovirology papers, a few trends stood out. First, a disproportionately large number of highly accessed papers focused on cellular restriction factors and their activities on HIV-1 [2-5], and in particular on the newly discovered and characterized SAMHD1 protein $[6,7]$. Second, papers on cellular innate immunity to retrovirus infection also captured interest $[8,9]$. Third, the topic of nuclear import of HIV-1 pre-integration complex remains popular $[10,11]$. Lastly, a paper published in Retrovirology only 10 months ago on microRNA changes in HIV-1 infected individuals [12] remarkably has elicited more than 4,400 accesses already, suggesting significant timely and topical interest. Twelve months from now, I will revisit these papers and their research areas to check how their citation frequencies bear out the interest reflected by their access frequencies.

This year marks a first change in Retrovirology editors. Michael Lairmore, an editor of Retrovirology since its inception in 2004, assumed the Deanship of the Veterinary College at the University of California, Davis. His new academic responsibilities precluded his continued editing duties with Retrovirology. With Michael Lairmore's departure, we welcome Persephone (Seph) Borrow of Oxford University as a new editor of Retrovirology. Seph brings to us added expertise in the immunology of

Correspondence: kjeang@nih.gov

The National Institutes of Health, Bethesda, MD, USA retroviruses, and the journal will look to her leadership in expanding the publishing of papers in this research area.

Retrovirology is also making a change in the frequency of the Retrovirology Prize, which was awarded to Masao Matsuoka of Kyoto University in 2011 [13]. To date, the Retrovirology Prize has been awarded annually. However, going forward, with a view towards increasing the selection stringency of our prize winners, the editors have decided to award this Prize on a biannual basis. The aim is to award the Retrovirology Prize in the same year as and at our biannual Frontiers of Retrovirology meeting (http://www.frontiers-of-retrovirology.com/). The rules for nomination and candidacy of the Retrovirology Prize remain the same, except that there will no longer be a distinction made between HIV vs. non-HIV virologists. With this editorial, we invite nominations for the 2013 Retrovirology Prize, which will be awarded at the Frontiers of Retrovirology meeting September 16-18 at Churchill College, Cambridge University, England.

\section{Acknowledgements}

The opinions expressed in this editorial represent KTJ's personal views and do not necessary reflect the views of his employer, the National Institutes of Health, USA. Research performed in KTJ's laboratory is supported by intramural funds from the NIAID, NIH. The author thanks Mark Wainberg and Ari Fassati for reading this editorial.

Received: 5 November 2012 Accepted: 8 November 2012 Published: 15 November 2012

\section{References}

1. Jeang KT: A measure of success. Cell Biosci 2012, 2:35.

2. Liu L, Oliveira NM, Cheney KM, Pade C, Dreja H, Bergin AM, et al: A whole genome screen for HIV restriction factors. Retrovirology 2011, 8:94.

3. Woods MW, Kelly JN, HattImann CJ, Tong JG, Xu LS, Coleman MD, et al: Human HERC5 restricts an early stage of HIV-1 assembly by a mechanism correlating with the ISGylation of Gag. Retrovirology 2011, 8:95. 
4. Sauter D, Hue S, Petit SJ, Plantier JC, Towers GJ, Kirchhoff F, et al: HIV-1 Group P is unable to antagonize human tetherin by Vpu, Env or Nef. Retrovirology 2011, 8:103.

5. Lukic Z, Hausmann S, Sebastian S, Rucci J, Sastri J, Robia SL, et al: TRIM5alpha associates with proteasomal subunits in cells while in complex with HIV-1 virions. Retrovirology 2011, 8:93.

6. St GC, Wu L: SAMHD1: a new insight into HIV-1 restriction in myeloid cells. Retrovirology 2011, 8:55.

7. Brandariz-Nunez A, Valle-Casuso JC, White TE, Laguette N, Benkirane M, Brojatsch J, et al: Role of SAMHD1 nuclear localization in restriction of HIV-1 and SIVmac. Retrovirology 2012, 9:49.

8. Borrow $P$, Shattock RJ, Vyakarnam A: Innate immunity against HIV: a priority target for HIV prevention research. Retrovirology 2010, 7:84.

9. Mogensen TH, Melchjorsen J, Larsen CS, Paludan SR: Innate immune recognition and activation during HIV infection. Retrovirology 2010, 7:54

10. De IA, Luban J: Inhibition of HIV-1 infection by TNPO3 depletion is determined by capsid and detectable after viral CDNA enters the nucleus. Retrovirology 2011, 8:98.

11. Cribier A, Segeral E, Delelis O, Parissi V, Simon A, Ruff M, et al: Mutations affecting interaction of integrase with TNPO3 do not prevent HIV-1 cDNA nuclear import. Retrovirology 2011, 8:104.

12. Witwer KW, Watson AK, Blankson JN, Clements JE: Relationships of PBMC microRNA expression, plasma viral load, and CD4+ T-cell count in HIV-1-infected elite suppressors and viremic patients. Retrovirology 2012, 9:5.

13. Matsuoka M: The 2011 Retrovirology Prize winner Masao Matsuoka: forward looking and antisense. Interview by Kuan-Teh Jeang. Retrovirology 2011, 8:102.

doi:10.1186/1742-4690-9-96

Cite this article as: Jeang: Highlights, predictions, and changes. Retrovirology 2012 9:96.

\section{Submit your next manuscript to BioMed Central and take full advantage of:}

- Convenient online submission

- Thorough peer review

- No space constraints or color figure charges

- Immediate publication on acceptance

- Inclusion in PubMed, CAS, Scopus and Google Scholar

- Research which is freely available for redistribution 